\title{
Comparison of the Spectrum of Outpatient visits before and after Fire in the Moria Camp after Arrival of Covid-19 Positive Refugees
}

\author{
M. Jackulikova (Maria Jackulikova) ${ }^{1}$, M. Tothova (Maria Tothova) ${ }^{3}$, J. Bydzovsky \\ (Jan Bydzovsky)3), M. Olah (Michal Olah) $)^{3}$, M. Bielova (Maria Bielova) $)^{3}$, I. Kmit

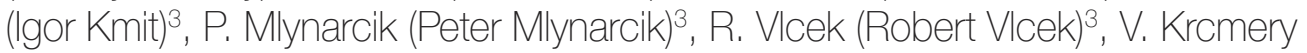 \\ (Nladimir Kromery)2, L. Nguyen (Lisa Nguyen) $)^{4}$
}

${ }^{1}$ SEU Refugee and Migrant Program UNHCR Camp Moria Lesbos, Greece.

${ }^{2}$ Slovak Medical University Bratislava Slovak Tropical Institute and Dept. of

Original Article Tropical Diseases SZU Bratislava, Slovakia.

${ }^{3}$ Refugee and Migrant Program St. John Paul II. School of Missiology and Dept. of Social Work Polianky, Slovakia.

${ }^{4}$ C.M.A Crisis Management Association, Greece.

\section{E-mail address:}

Maria.jackulikova@gmail.com

\section{Reprint address:}

Maria Jackulikova

C.M.A Crisis Management Association,

Mytilene, Lesbos

Greece

Source: Clinical Social Work and Health Intervention

Pages: $28-30$

Volume: 12

Issue: 1

\section{Reviewers:}

Vlastimil Kozon

AKH Vienna

Victor Namulanda PhD

MIC Nairobi

\section{Keywords:}

Refugees. Migrants. COVID-19.

\section{Publisher:}

International Society of Applied Preventive Medicine i-gap

CSWHI 2021; 12(1): 28 - 30; DOI: 10.22359/cswhi_12_1_07 (C) Clinical Social Work and Health Intervention

Abstract:
Cited references: 2 
Change of the spectrum was caused by fire related psychotrauma and absence of housing for a week, until complementary sheltering facilities were arranged.

\section{Introduction}

Moria Refugee Camp for Syrian, Iraqi, Afghan and other Middle East refugees of war and economic migrants has been operating for 12 years with an original capacity of 2,000 migrants and refugees. However, since 2018, this capacity was exceeded 6-7 times. Arrival of the first Covid-19 positive individuals was reported on Sept. $2^{\text {nd }}$ followed by a forced quarantine of about 20 recently arrived migrants which caused unrest followed by fire destroying the original campus. Comparison of diagnoses of migrants and refugees arriving to the Moria Camps before and after fire destroying the original sheltering facilities on Lesbos Island. Upheavals and unrest after arrival of the first group of Covid 19 positive individuals discussed in this research pilot note.

\section{Methods}

This is a single setting single cohort study of the vulnerable refugee and migrant populations with the majority of Afghani Tajik Persian origin followed by Ethiopia and Sub-Saharan Africa nationals. This spectrum is very different from those arriving from Turkey in 2015-2018 where Iraqi and Syrian nationals were prevalent in $80 \%$ of arrivals. Two periods are compared concerning the spectrum of diagnosis-before the camp destroying fire (June to Sept.) and after the fire (Oct to Nov), causing 12,000 unsheltered and camping migrants including mothers, seniors and children for at least 5 days.

\section{Results and Discussion}

Table 1 analyses the spectrum of OPD admissions in our Outpatient Department inside the Moria UNHCR Camp and after the fire in mobile and sheltered OPD. In the first period until the fire outbreak, wounds and travel related injuries were commonest followed by: upper RTI due to overcrowding; with scabies as well due to lack of access to proper hygiene in the over populated camp.

After the devastating fire, psychosomatic related civilization diseases decompensated such as hypertension, diabetes and asthma, neurotic gastritis. Camping in nature for next 5 days led to outbreaks of RTI, wound and scabies related infections as a logic consequence of limited housing shelters.

\section{Conclusions}

The only positive feature of the devastating fire was a rapid transfer of unaccompanied minors to mainland Greece and other EU destina-

Table 1 Comparison of major diagnoses before and after the destroying fire in Lesbos Island UNHCR Camp Moria

\begin{tabular}{|ll|}
\hline \multicolumn{2}{|c|}{ Weekly admissions in OPD average 255............500 approx } \\
\hline Before the destroying fire & after the event (Oct - Nov) \\
\hline Wounds 51\% & $\begin{array}{l}\text { hypertension } \\
\text { diabetes decomp } \\
\text { asthma } \\
\text { psychomotoric gastritis }\end{array}$ \\
\hline Upper RTI 21\% & upper respiratory tract inf \\
\hline Scabies lice 19\% & $\begin{array}{l}\text { covid 19 } \\
\text { cabies, dental infection }\end{array}$ \\
\hline Gastritis 9\% & \\
\hline Dental infection 5\% & \\
\hline Two dg at once 5\% & \\
\hline
\end{tabular}


tions. The rest of the refugees were placed in provisional shelters and before winter shall be partially dispersed to the mainland to get better health care. The number of visits increased after the fire from 250 to 500 so the demand for health services increased by $100 \%$ due to non-communicable diseases related to stress such as coronary heart and neurologic diseases, psychoses, insomnia, depression, which may aggravate diabetes hypertension and asthma.

\section{References}

1. UNHCR ANNUAL REPORT BRANCH GREECE (2018) p. 145.

2. PERI H A, SUBRAMANIAN S, SLADECKOVA V, BYDZOVSKY J, DURCOVA B, KUBALIKOVA Z, OLAH M, MATULNIKOVA L, DOKTOROV A, BERESOVAA, KUBIK F, FULA M, OTRUBOVA J, KALATOVA D, KUKUCKOVA E, JURINOVA S, BENCA J, SHAHUM A, HOY LEANG HOINAND CHENG HOIN, SETA S/ Early detection of adverse therapy reaction in orphan children with AIDS (short communication) / In: Acta Missiologica. - ISSN 13377515. - Vol. 13, no. 2 (2019) p. 184-187. 